\title{
Analysis of two whale shark watching destinations in Indonesia: status and ecotourism potential
}

\author{
ASRIL DJUNAIDI ${ }^{1, \boldsymbol{v}}$, JAMALUDDIN JOMPA $^{1}$, NADIARTI NADIARTI ${ }^{1}$, AHMAD BAHAR $^{1}$, \\ SUKIRMAN DJ. TILAHUNGA ${ }^{2}$, DEBORAH LILIENFELD ${ }^{3}$, MAULITA SARI HANI ${ }^{4}$ \\ ${ }^{1}$ Faculty of Marine Science and Fisheries, Universitas Hasanuddin. Jl. Perintis Kemerdekaan Km. 10, Tamalanrea, Makassar 90254, South Sulawesi, \\ Indonesia. Tel./fax.: +62-411-586025, `email: adjunaidi68@gmail.com \\ ${ }^{2}$ Tourism Department of Bonebolango District. Lombongo, Suwawa Tengah, Bone Bolango 96583, Gorontalo, Indonesia \\ ${ }^{3}$ Intention Ventures. Rua Barbosa de Freitas, 1741 60.170-021- Aldeota, Fortaleza, Ceará, Brazil \\ ${ }^{4}$ Conservation International Indonesia. Jl. Pejaten Barat Raya No.16A, RT.1/RW.10, Ragunan, Pasar Minggu, Jakarta Selatan 12550, Jakarta, Indonesia
}

Manuscript received: 18 May 2020. Revision accepted: 29 September 2020.

\begin{abstract}
Djunaidi A, Jompa J, Nadiarti N, Bahar A, Tilahunga SD, Lilienfeld D, Hani MS. 2020. Analysis of two whale shark watching destinations in Indonesia: status and ecotourism potential. Biodiversitas 21: 4911-4923. Botubarani in Gorontalo, on the northern coast of Tomini Bay and Labuhan Jambu in Teluk Saleh, Sumbawa recently became whale shark tourism destinations in Indonesia. Both sites offer visitors opportunities to interact with whale sharks, either watching from canoes or snorkelling and diving. In this study, we investigated the status and ecotourism potential of whale shark watching as a form of marine wildlife tourism development in eastern Indonesia by examining the existing operations in both sites. Data were collected using questionnaires administered to local community members and visitors to understand their perceptions, and how this opportunity was valued. Secondary data were collected to explore and understand influencing factors. Findings revealed that whale sharks commonly emerge near bagan lift-nets and other interactive areas as a response to the presence of their favorite prey, anchovies, and rebon shrimp. In general, whale sharks most commonly visit bagan lift nets and can be found in the interaction areas in the morning and stay for couple of hours before swimming away to deeper waters. Out of 119 community respondents in Labuhan Jambu village (Teluk Saleh) and Botubarani, Gorontalo, 80.7\% knew about the occurrence of whale sharks in their locality. Of the 111 visitor respondents, $67.6 \%$ knew about the whale shark watching sites from word of mouth. The study results also suggest a correlation between chlorophyll-a concentration, anchovies, rebon shrimp and whale sharks. Regarding management approaches to this type of tourism, a local community-based management model is strongly recommended, with $87.4 \%$ of respondents showing interest in this approach. The roles and responsibility of local government in developing such tourism is very significant, especially with respect to facilitating appropriate competency within the local community throughout training and education, as suggested by nearly $26 \%$ of respondents.
\end{abstract}

Keywords: Ecotourism, lift-net, marine wildlife tourism, sustainable tourism, whale shark tourism

\section{INTRODUCTION}

The whale shark, Rhincodon typus, has a global distribution in tropical and subtropical oceans (Compagno 2001), and is the world's largest fish alive today. Whale sharks feed on plankton and travel long distances to find enough food to sustain their huge size, and to reproduce (Robinson et al. 2013). The maximum size of whale sharks is not known but could be as large as 20 meters (Robinson et al. 2013). Females give birth to live young, but this has never been observed; where pupping occurs and where the youngest animals spend their time remains a mystery, as they are very rarely found (Motta et al. 2010). Adults are often found feeding at the surface but may dive to 1000 meters. In addition, whale sharks are known to feed on a variety of planktonic and nektonic organisms by flexibly using surface ram feeding, sub-surface filter-feeding, or stationary suction feeding (Motta et al. 2010). These animals are known to aggregate seasonally in a number of areas, including Western Australia, Belize, Northern Mexico, Philippines, Djibouti, Mozambique, the Maldives and Seychelles (Robinson et al. 2013). It is generally thought that these migrations are usually in response to regular or seasonally driven shifts in planktonic food sources (De la Parra et al. 2011). Known whale shark aggregations all occur close to coasts or reefs and are usually dominated by juvenile and sub-adult males (Brooks et al. 2011; Rowat et al. 2011).

Whale sharks are highly valued in international markets (Rowat et al. 2011). As a highly migratory species, whale sharks are exposed to many anthropogenic activities including illegal, unreported, and unregulated (IUU) fishing (Anna 2017). Demand for their meat, fins, and oil remains a threat to the species, particularly by unregulated fisheries (Rowat et al. 2011). They are also victims of bycatch, the accidental capture of non-target species in fishing gear (Rowat et al. 2011). Whale shark tourism can also present a potential threat to the species as it can interrupt their feeding and sharks can be injured by boat propellers (Brooks et al. 2011). Although whale sharks are protected from fishing in some countries these days, many populations are in decline (Brooks et al. 2011). The International for the Conservation of Nature (IUCN) has placed this species in its Red List with the status of 
Vulnerable (IUCN 2011) because of an estimated population decline between $20-25 \%$ over the past 10 years (Pierce and Norman 2016). This fish is also listed in Appendix II of the Convention on International Trade in Endangered Species (CITES) which requires regulations on the trade in this species and any products thereof, in order to minimize population decline (Anna 2017).

A good environment with optimal conditions for foraging will tend to attract whale sharks to aggregate. Sites with predicted seasonal foraging aggregations of whale sharks offer opportunities to study the species, in particular studies on whale shark occurrence and abundance (e.g. Rowat and Brooks 2012; Himawan et al. 2015; Macena and Hazin 2016; Ranintyari et al. 2018). Their white spotted coloration makes these gentle giants easy to distinguish; they are popular with snorkellers and divers at sites where they aggregate off the coast, as they offer great opportunities for people to interact with them. These sites appeal to the growing global tourism industry, and whale shark tourism can provide an alternative income generation option to local communities in some destination areas. For example, in Teluk Cenderawasih the total economic value of whale shark tourism is reached IDR 142.35 billion per year (Anna 2017). Meanwhile, in Australia alone, over 100 wildlife tour operators collectively generate several billion dollars annually in revenue (Higginbottom et al. 2001). In Botubarani, there was anecdotal evidence that in 2018 the average total income from whale shark watching was approximately IDR 250 billion per year which is IDR 21 billion per month (Iman Tilahunga, pers.com. 2018).

Whale sharks have been sighted in many places in Indonesia, including Probolinggo, Gorontalo, Teluk Saleh, Kaimana, and Teluk Cendrawasih (Anna 2017). These sightings mostly occurred close to floating lift nets called bagan, where the whale sharks can feed on anchovies and rebon shrimp (Acetes sp.) which are both among their preferred prey. However, at Botubarani in Tomini Bay the whale sharks do not aggregate around lift nets; instead, they appear at the sea surface in their search for seasonal schools of migratory fish larvae known locally as nike (Himawan et al. 2017). These nike are the larvae of several species of goby (thought to be Awaous sp.) which spend most of their lives in freshwater but have a larval stage in estuarine or coastal seawater (Olii et al. 2017). In addition, some researchers have suggested that chlorophyll concentrations in the sea surface layer can be used to indicate the spatial distribution and help predict the presence of whale sharks (Ranintyari et al. 2018; Ihsan et al. 2018).

Recognizing the threats facing whale sharks, several strategies have been proposed to protect this fish. Strategies adopted by governments include the establishment of Marine Protected Areas and support for the development of whale shark watching tourism as an alternative livelihood opportunity for coastal communities in eastern Indonesia. Two sites where such developments have been supported by local governments are Botubarani in Gorontalo Province and Labuhan Jambu in Nusa Tenggara Barat (NTB) Province. This study aimed to investigate the status of whale shark watching ecotourism and its potential to contribute to wildlife marine tourism development in Eastern Indonesia. The study focused on the existing whale watching tourism operations at these two sites, as well as the factors potentially affecting the occurrence of whale sharks in the study area.

\section{MATERIALS AND METHODS}

\section{Methods}

This study was undertaken at two sites with whale shark watching tourism operations in Indonesia, i.e.: Botubarani, off the Tomini Bay coast of Gorontalo Province, and Labuhan Jambu, Teluk Saleh in Sumbawa, West Nusa Tenggara Province (Figure 1).

Primary data were collected on human population demographics, tourism development, community perceptions, visitor country of origin, numbers and participation. Questionnaires were distributed to residents and visitors at both sites. These questionnaires were deployed on-site by four trained enumerators from 15 June to 15 October 2018, and completed questionnaires were returned by 119 community respondents and 111 visitors. Visitors in this study come to study areas every day and spend time there.

In order to gain a more holistic understanding of the operation of existing whale shark watching tourism in the study areas, several key informant interviews and focus group discussions were held. Direct observation methods were also used during the study period with visits to bagan in Labuhan Jambu, Teluk Saleh, and come to interaction area in Botubarani, Gorontalo to watch whale sharks while swimming, snorkelling and diving. According to Macena and Hazin 2016, there are two ways to record the occurrence of whale sharks, one is a sighting survey through direct observation by stay on board and second is to use free diving or snorkelling observers.

Secondary data were collected on tourism infrastructure, facilities, bagan lift nets, and the seasonal movements of whale sharks. These secondary data were collected through internet searches, from the scientific literature, grey literature (e.g. reports and unpublished studies), and contact with government agencies, nongovernmental organizations and ecotourism operators.

By coding the questionnaire data in SPSS v24 IBM, qualitative data collected were converted to quantitative data. Prior to data processing, data validation was performed and data were checked using the validation routine in SPSS v24 IBM to ensure reliability and compliance with the assumptions for the statistical tests used. Descriptive statistical analyses were used to evaluate the result of this study. In addition, respondent replies to all multiple answer questions were analyzed by means of the multiple response routine in SPSS v24 IBM. These processed data were tabulated and analyzed graphically and descriptively. Information collected from focus group discussion and key informant interviews as well as secondary data were used to re-confirm (cross-check) the results of the statistical analysis based on the questionnaire. 


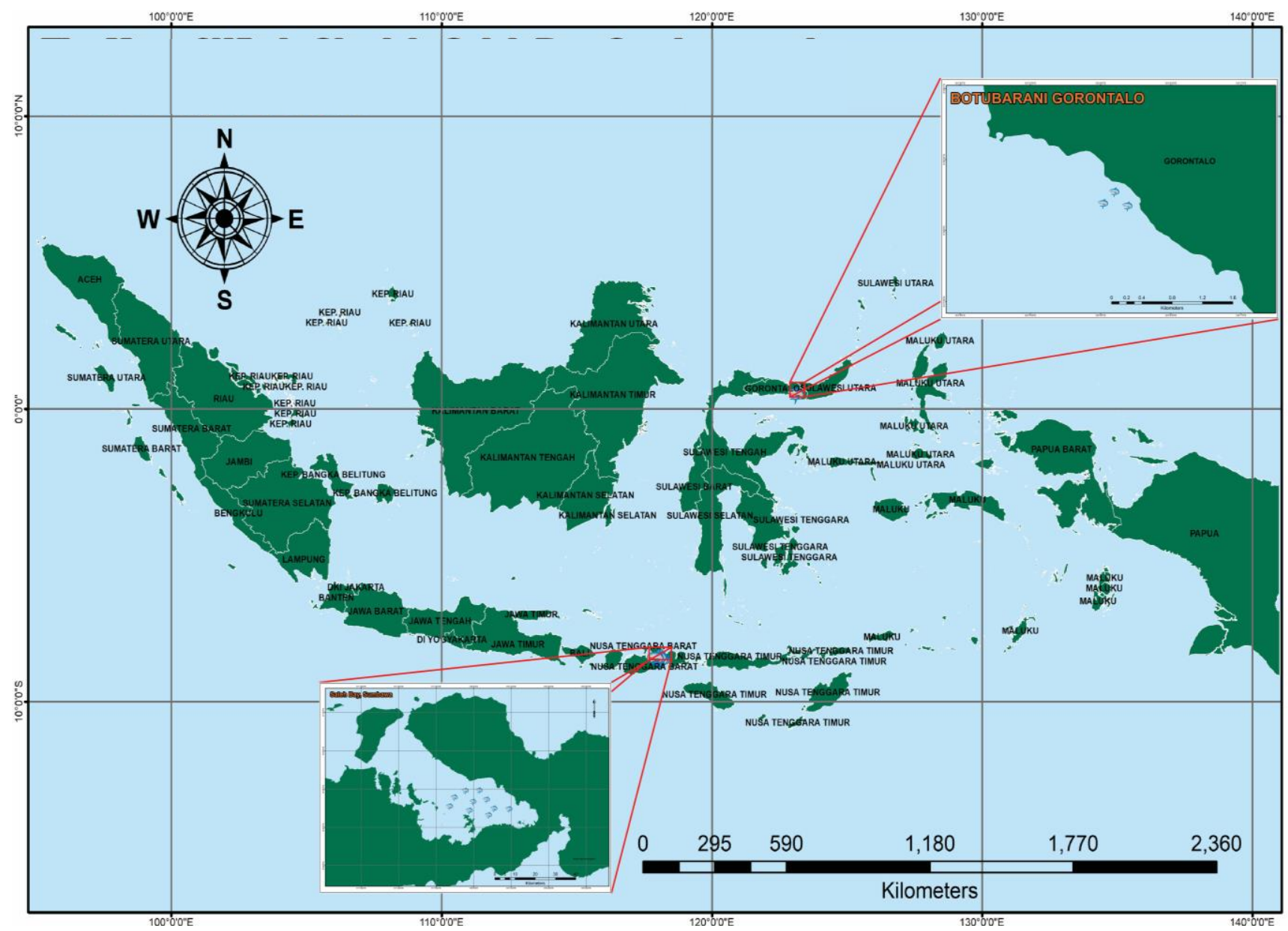

Figure 1. Map showing the study sites: Botubarani, Gorontalo and Labuhan Jambu, Teluk Saleh, Sumbawa, Indonesia

\section{RESULTS AND DISCUSSION}

\section{Demographics of local communities in Labuhan Jambu and Botubarani}

Local community respondent demographics collected (for the two sites combined) included status, age, sex, and education (Table 1). In terms of status, the majority (nearly $80 \%$ ) were married, and they were fairly evenly spread across age groups with a plurality in the 31-40 years old range and a slightly male-biased sex ratio (1.12:1). In terms of educational attainment, just over a third had completed elementary school, while the majority $(55.5 \%)$ had completed either junior or senior high school and approximately $10 \%$ had completed some form of tertiary education.

\section{Global distribution of whale sharks}

The whale shark (Rhincodon typus) is a large (up to 18 $\mathrm{m}$ in length) migratory species and filter-feeder that inhabits tropical and warm-temperate waters worldwide (Pierce and Norman 2016). Although they are principally oceanic, whale shark aggregations occur in the shallow coastal waters of many countries. These aggregations take place for a few months of the year and because of their predictability, they become a focus of substantial ecotourism industries (Rowat and Brooks 2012). Globally, whale sharks have been found to aggregate in various locations, and some effort has been made to try to find common characteristics between these locations (Rowat and Brooks 2012). Macena and Hazin 2016 have collected a series of data in order to better understand the distribution and aggregation of whale sharks. They found that $R$. typus is predominantly found in warm waters between $20-30^{\circ} \mathrm{C}$ in both Western Australia and in the Sea of Cortez, although this fish has been reported in waters with temperatures as low as $10^{\circ} \mathrm{C}$. Compagno (2001) has illustrated the global distribution of whale sharks (Figure 2).

Knowledge of the distribution of whale sharks in Indonesia is still incomplete. However, there are ongoing efforts to improve our knowledge, and various organizations have been collecting data and information on whale shark occurrences through direct observation and by collecting information from fishers, many of which are unpublished or only available in the so-called "grey literature" such as internal reports of government and nongovernment agencies, unpublished student theses and other research reports. Whale sharks have been observed in two ways, either from on-board a vessel or in the water where snorkellers or divers approach the whale sharks and swim with them. In either case, photographs may be taken and specific features may be noted. Table 2 shows a summary of places where the whale sharks are known to be commonly sighted. Data collected from various unpublished sources were compiled to produce this table. 
Table 1. Summary of frequency and percentage of education, age, sex, and status of community

\begin{tabular}{lll}
\hline Parameter & Frequency & Percentage \\
\hline Education & & \\
Elementary School & 41 & $34.5 \%$ \\
Junior High School & 29 & $24.4 \%$ \\
Senior High School & 37 & $31.1 \%$ \\
Tertiary Education College & 2 & $1.7 \%$ \\
University & 10 & $8.4 \%$ \\
Age & & \\
18-25 & 28 & $23.5 \%$ \\
$26-30$ & 15 & $12.6 \%$ \\
$31-40$ & 32 & $26.9 \%$ \\
$41-50$ & 24 & $20.2 \%$ \\
$\geq 50$ & 20 & $16.8 \%$ \\
Sex & & \\
Male & 63 & $52.9 \%$ \\
Female & 56 & $47.1 \%$ \\
Status & & \\
Married & 94 & $79.0 \%$ \\
Not Married & 19 & $16.0 \%$ \\
Divorced & 6 & $5.0 \%$ \\
\hline
\end{tabular}

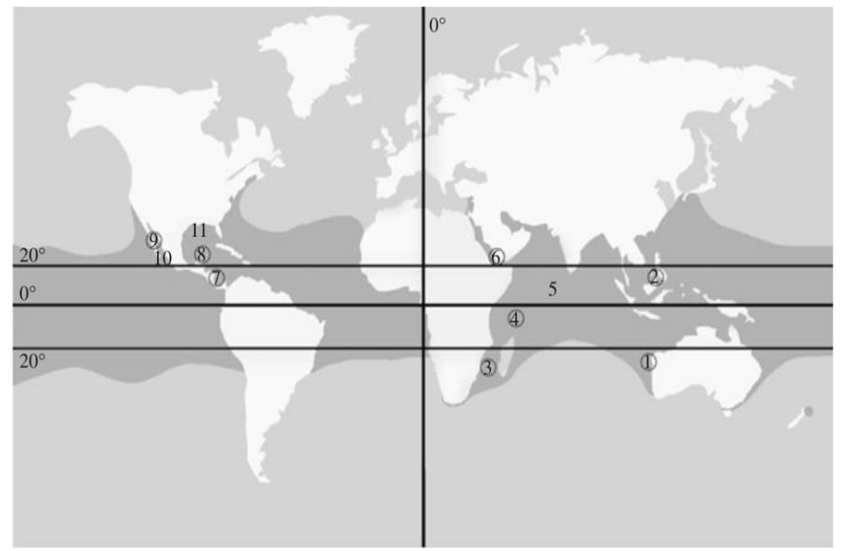

Figure 2. Global distribution range of Rhincodon typus with several known aggregation areas: 1 . Ningaloo; 2. Philippines; 3. Mozambique; 4. Seychelles; 5. Maldives; 6. Djibouti; 7. Belize; 8. Holbox; 9. North Gulf of California; 10. South Gulf of California; 11. North Gulf of Mexico. Circled numbers indicate areas with dedicated R. typus tourism activities (source: Compagno 2001).

Table 2. Indonesian sites where whale shark sightings are common (compiled from various unpublished sources)

\begin{tabular}{llccl}
\hline Location & Reported sightings & Length (m) & Number of individuals & Remarks \\
\hline Anambas, Riau & July 2006 & $3-4$ & 1 & Reported by fishers \\
Pesisir Selatan, West Sumatera & April 2007 & 5 & 1 & Reported by fishers \\
Pangandaran, West Java & September 2010 & 4 & 1 & Reported by fishers \\
Kendal, Central Java & February 2009 & 7 & 2 & Reported by fishers \\
Jepara, Central Java & December 2007 & 3 & 1 & Reported by fishers \\
Surabaya, East Java & October 2009 & 7 & 1 & Reported by fishers \\
Banggai Kepulauan & May 2009 & 5 & 1 & Photo-ID \\
Probolinggo, East Java & January 2009 & 5 & 26 & Photo-ID \\
Botubarani, Gorontalo & June 2018 & $4-12$ & 42 & Photo-ID \\
Labuhan Jambu, Teluk Saleh & All year around & $4-12$ & 126 & Photo-ID \\
Teluk Cendrawasih & All year around & $4-12$ & & Photo-ID \\
\hline
\end{tabular}

The Agency for Coastal and Marine Resources Management (BPSPL Makassar) has reported that 19 individual whale sharks have been identified in Botubarani, Gorontalo Province. The number of whale sharks sighted is normally around 6 individuals per day. In addition, fishers reported that they often sighted groups of between 8 to 10 whale sharks during fishing. One difference with the other sites was that whale sharks in Botubarani were also stimulated to congregate by intentional feeding with the head and carapaces of vannamei shrimp (Litopenaeus vannamei) to provide a tourism attraction (Tania 2014 and Himawan et al. 2017).

Fishermen from both Labuhan Jambu and Botubarani actively seek for whale sharks, as they believe that many target fish will be found nearby. According to these fishermen, June is the peak season for whale shark sightings. During surveys in Teluk Saleh, we sighted 4 whale sharks in May 2018, and 7 whale sharks in June 2018 , both close to bagan lift nets. According to a local fisherman in Labuan Jambu village (Teluk Saleh,
Sumbawa), the emergence of whale sharks in this area has been observed since 1992 (Bapak Budiamin, personal communication 2018).

\section{Photo-ID approach to support conservation strategies Botubarani, Gorontalo}

The procedure to take a photo-ID is that snorkelers or divers prepare an underwater camera then wait for the whale sharks to come. As soon as a whale shark comes, the snorkelers or divers swim near the fish and take photographs of the pectoral fins (left and right). The BPSPL Makassar has been taking photo-IDs of whale sharks since beginning of 2017. During the first eleven months of 2017, the BPSPL Makassar and Whale Shark Indonesia reported the recording of 32 individual whale sharks using photo-ID in the Botubarani tourism interaction area (BPSPL Makassar 2017; Himawan et al. 2017). Figure 4 shows examples of photo-ID frames taken from both pectoral fins of two male whale sharks observed in Botubarani. 

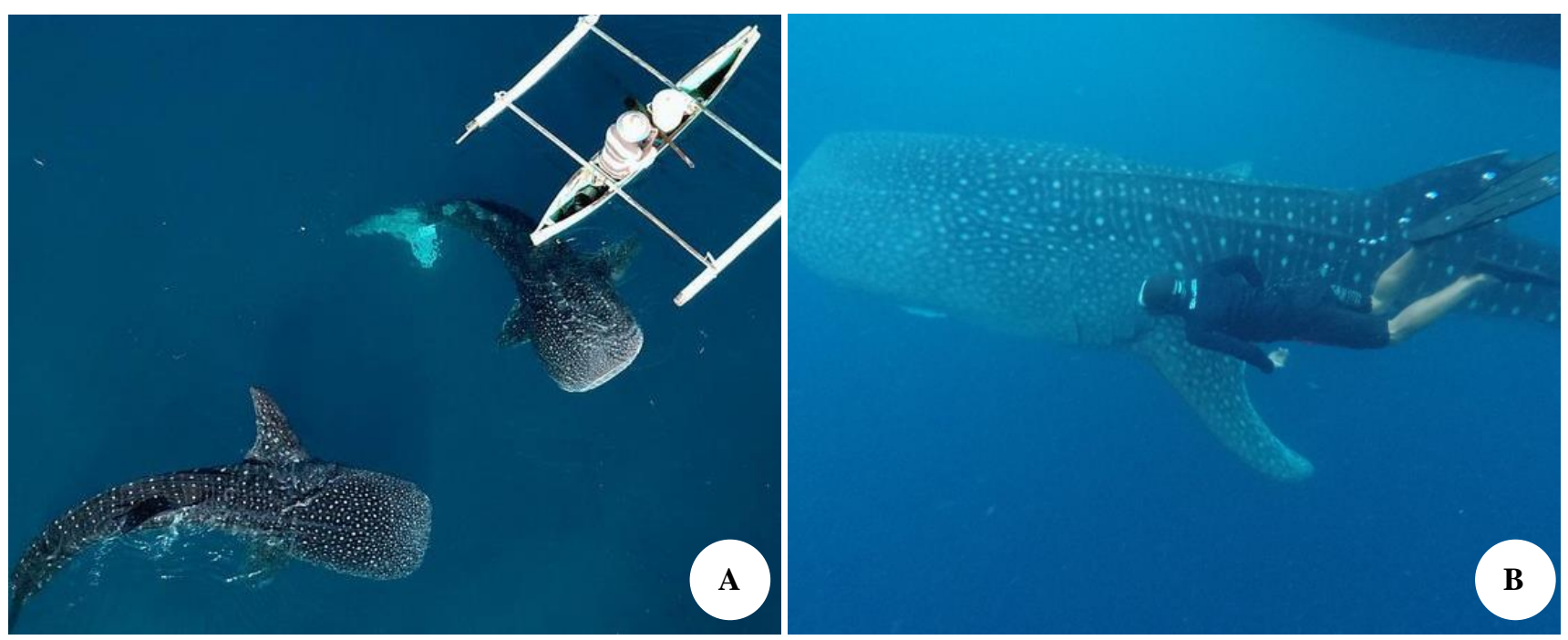

Figure 3. A. Whale shark sightings in Botubarani, Gorontalo, Indonesia (Source: https://www.tripadvisor.com/Attraction_Reviewg1602653-d10802035-Reviews-Whale_Shark_Sightseeing_Spot-Gorontalo_Gorontalo_Province_Sulawesi.html), B. Labuhan Jambu, Teluk Saleh, Sumbawa, Indonesia (Source: Asril Djunaidi)

ID Individual ID GT- 02 Male Total length 6 meters
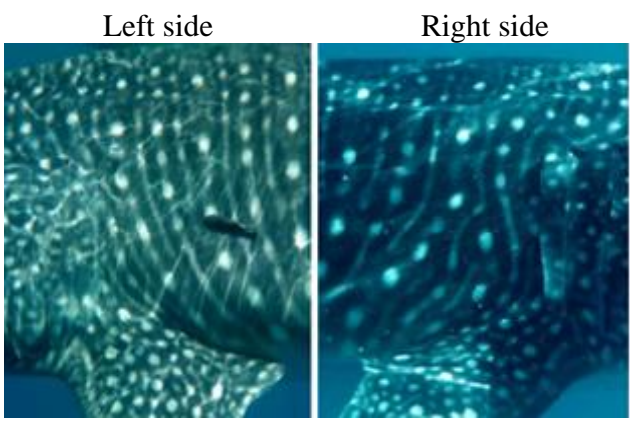
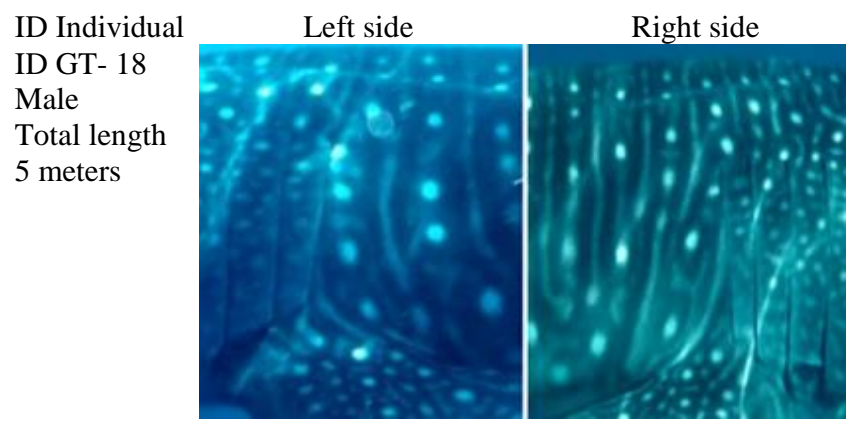

Figure 4. Photo-ID frames showing both left and right pectoral fins of two whale sharks in Botubarani, Gorontalo, Indonesia (Source: BPSPL Makassar 2017)

\section{Labuhan Jambu, Teluk Saleh, Sumbawa}

The Photo ID method described above has also been used by Conservation International Indonesia to identify whale sharks in Labuhan Jambu, Teluk Saleh since 2017. Through their monitoring program, they have identified 42 individual whale sharks commonly aggregating at this site (Conservation International Indonesia 2018). The Photo ID frames of the pectoral fins of a female whale shark observed at this site are shown in Figure 5.

At Labuhan Jambu, whale sharks are commonly sighted around bagan (a lift-net fishing gear). The bagan fishermen target anchovies and a type of small shrimp with the local name of rebon. The presence of whale sharks is thought to be a response to the presence of their favored prey, anchovies, and rebon. The whale sharks normally appear around the bagan lift nets early in the morning and tend to disappear after few hours, moving back to deeper waters. According to data from the village of Labuhan Jambu, there are at least 77 bagan operated in Teluk Saleh and they employ approximately 368 people. This fishery plays a significant role in the local economy. Local monthly income in this village from the bagan lift net fishery alone is estimated at around IDR 25 million per fortnight.

\section{Chlorophyll distribution in Labuhan Jambu, Teluk Saleh}

The information on chlorophyll distribution is significant because many researchers have suggested that the distribution of chlorophyll-a in the water column and the presence of anchovies can be utilized as an indicator of whale shark distributions. For example, Macena and Hazin 2016 carried out the research in archipelago of São Pedro and São Paulo and used chlorophyll-a in order to determine the whale shark distribution in the area. Cárdenas-Palomo et al. 2014 collected both chlorophyll-a and zooplankton biomass from May to September 2013 in the waters around the Yucatan Peninsula and reported that Rhincodon typus aggregate during these months. In addition, it has been suggested that the timing of whale shark aggregations often corresponds with local blooms of phytoplankton or with the spawning of fishes or corals (Riley et al. 2009). 
Whale shark ID number SB-RT-001 Female Total length 4 meters

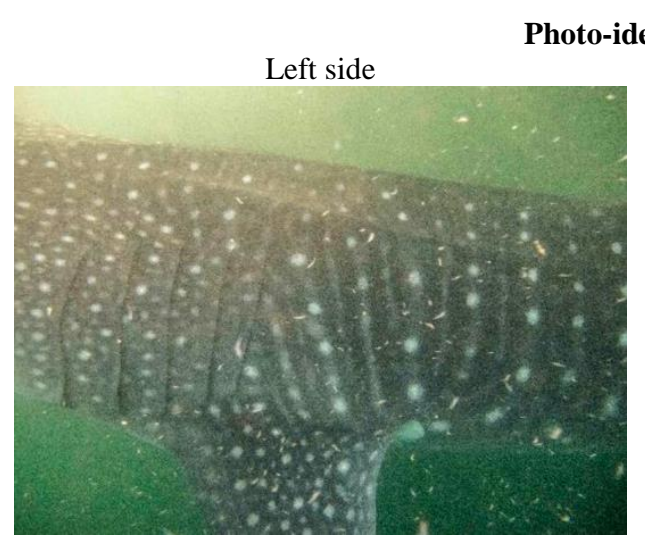

\section{Photo-identification}

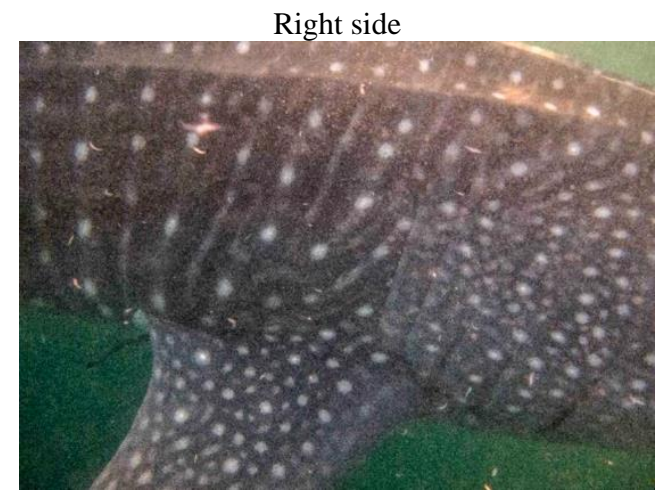

Figure 5. Photo-ID frames of the pectoral fins of a female whale shark observed in Labuhan Jambu, Teluk Saleh, Sumbawa, Indonesia (Source: Conservation International Indonesia 2018)

Information on the distribution of chlorophyll-a in Teluk Saleh, (Yulianto et al. 2016) is presented in order to help better understand the movements of whale sharks (Figure 6). Other studies have suggested that high levels of chlorophyll-a are also associated with Acetes sp., small krill-like shrimps locally called rebon or masin (Yulianto et al. 2016). According to Budiamin (a fisherman from Labuan Jambu), whenever the small rebon shrimp appear, this triggers the whale sharks to come; this is an obvious case of the food chain principle being applied.

\section{Community participation in whale shark tourism}

Viewing whale sharks in their natural setting is a popular tourism activity (Gallagher and Hammerschlag 2011) and the income accrued can create an incentive to manage these charismatic species as a non-consumptive resource (Brunnschweiler 2010; Clua et al. 2011; Vianna et al. 2012). Many countries where whale sharks are found conduct such tourism activities to create income for the local people. However, this tourism must be well managed otherwise it can have negative impacts including changes in whale shark behavior (Pierce et al. 2010; Fitzpatrick et at. 2011; Haskell et al. 2015).

In the process of sustainable tourism development, community perception, participation, and empowerment are considered a critical component of success. This study attempted to assess these components. Participation is a vital component of the self-help process and people must be involved in the decisions that are likely to affect their quality of life. Through participation, they gain confidence, self-esteem, and knowledge, and develop new skills (Nikkhah and Redzuan 2009). In community-based ecotourism, focusing on environmental, social, and cultural sustainability is a key approach to success and plays a vital role in meeting the challenge of sustainability in tourism (UNEP 2011). To make appropriate decisions from an environmental perspective, an individual needs to have a clear understanding of the environmental issues (Hayombe et al. 2012; Zhang and Lei 2012).

Through participation, the community would have opportunities to decide on the direction of development they would like to see. Several hierarchies of community participation have been described, such as the "ladder of citizen participation" proposed by (Arnstein 1969). Other classifications of community participation described in (Daldeniz and Hampton 2012) include the three clusters of direct participation, induced participation, and coercive participation proposed by Tosun and the Pretty and Hine typology of participation comprising manipulative participation, passive participation, participation by consultation, participation for material incentive, functional participation, interactive participation, and selfmobilization. These three hierarchies are summarized in Table 3 (Daldeniz and Hampton 2012).

To explore the kind of participation communities in the study area would prefer, we asked a question on participation with three options based on the Tosun threetier concept. The results (Figure 7.A) show that $84.9 \%$ of respondents preferred direct and active participation, while only $10.1 \%$ chose indirect and passive participation, and only a very small percentage selected coercive participation $(5.0 \%)$ with total $\mathrm{N}=119$.

To gain a more in-depth perception of community participation in managing whale shark tourism, we offered the respondents three models to choose from. The results (Figure 7.B) show that around two-thirds of community members preferred the model "owned and managed by local community" (87.4\%), while over a quarter chose "owned by outsiders and managed by locals" (10.1\%) while a small minority selected "owned and managed by outsiders" $(2.5 \%)$ with total $n=119$. One interesting finding from the study was that, during the process of initiating the development of whale shark tourism in Botubarani and Labuan Jambu, local communities had been involved. There had been meetings at which stakeholders had discussed the issues together. 

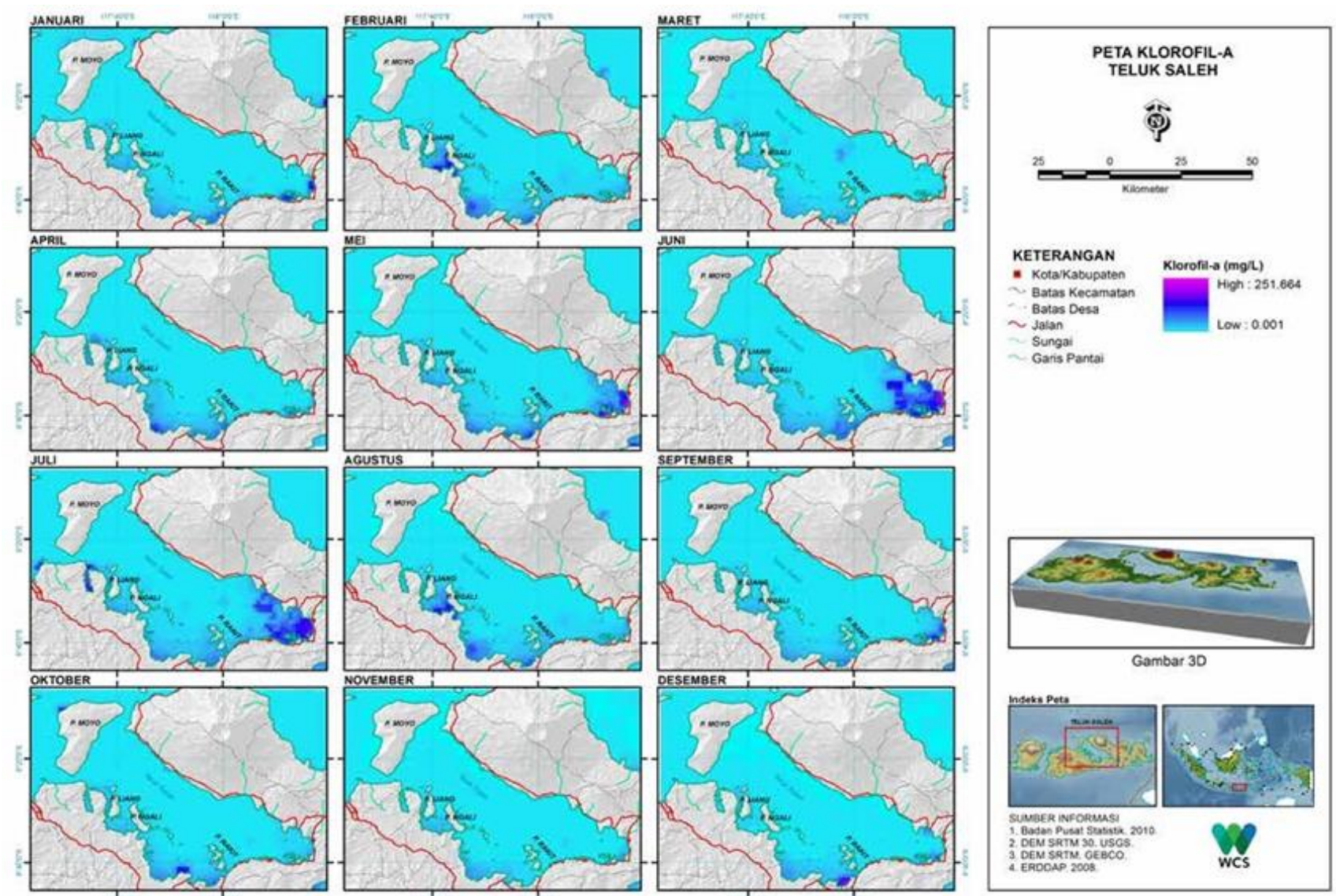

Figure 6. The distribution of chlorophyll-a in Teluk Saleh, Sumbawa, Indonesia (Source: WCS report / Yulianto et al. 2016)

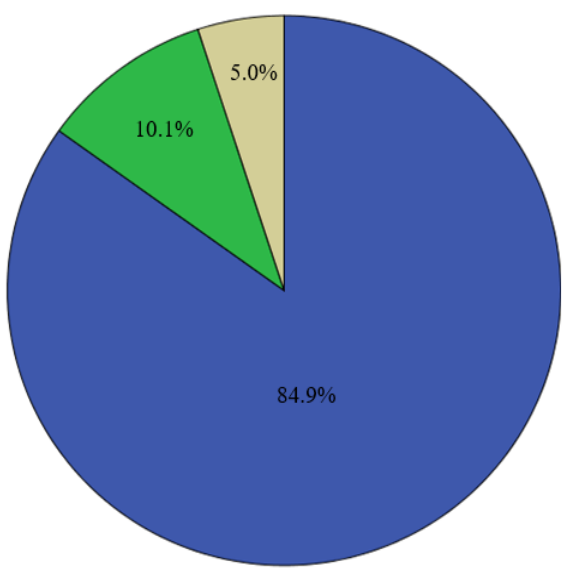

A

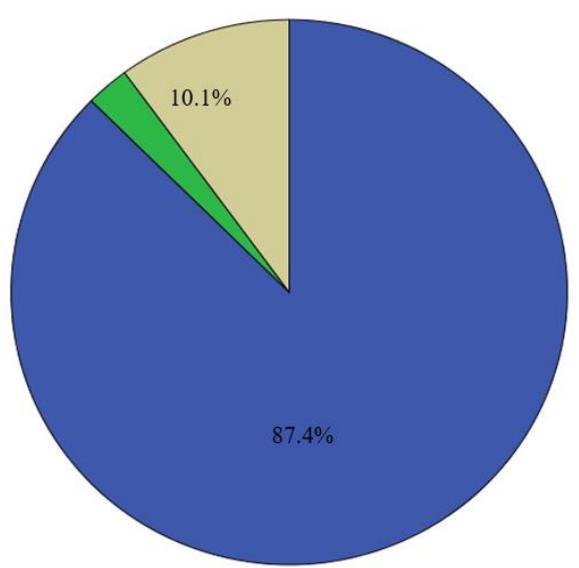

B

Figure 7. A. Type of participation community members would prefer. Note: Blue: direct and active participation; Green: indirect and passive participation; Grey: coercive participation (total $n=119$ ); B. Management model that communities would prefer. Legend: Blue: owned and managed by local community; Grey: owned by outsiders and managed by locals; Green: owned and managed by outsiders (total $\mathrm{n}=119$ )

\section{Government roles and responsibilities}

In this study we asked community members for their opinion regarding the roles and responsibilities of government, with four options: provide training; promotion; provide infrastructures; and provide regulation. The results of multiple responses from 2 study sites combined (Table 4) showed that each of the four options was selected as the primary or most important role of government services by around a quarter of the respondents, and all four options were deemed important by a large majority of respondents. 
Table 3. Summary of normative typologies of community participation (Daldeniz and Hampton 2012)

\begin{tabular}{llll}
\hline \multirow{2}{*}{ Level } & \multicolumn{3}{c}{ Typology of community participation } \\
\cline { 2 - 4 } & \multicolumn{1}{c}{ Pretty (1995) } & \multicolumn{1}{c}{ Arnstein (1969) } & \multicolumn{1}{c}{ Tosun (1999) } \\
\hline Level 1 & 7. Self-mobilization & 8. Citizen control & Spontaneous participation: bottom-up; active participation; \\
& 6. Interactive participation & 7. Delegated power & direct participation; participation in decision making; authentic \\
& & 6. Partnership & participation; self-planning
\end{tabular}

Level 2 5. Functional participation 5. Placation

4. Participation for material Incentive 4. Consultation

3. Participation by consultation 3. Informing

Level 3 2. Passive participation

1. Manipulative participation

2. Therapy

1. Manipulation
Induced participation: Top-down; passive; formal; mostly indirect; degree of tokenism; manipulation

Pseudo-participation; participation in implementing and sharing benefits; choice between proposed alternatives and feedback

Coercive participation: top-down, passive; mostly indirect; formal; participation in implementation, but necessarily sharing benefits; choice between proposed limited alternatives or no choice; paternalism; non-participation; high degree of tokenism and manipulation.

Level 4 Non-participation

Table 4. Perception of respondents from Labuhan Jambu and Botubarani communities regarding the roles and responsibilities of Government Services

\begin{tabular}{lccc}
\hline \multirow{2}{*}{$\begin{array}{c}\text { Type of government } \\
\text { service roles }\end{array}$} & $\begin{array}{c}\text { Number of } \\
\text { respondents }\end{array}$ & \multicolumn{2}{c}{$\begin{array}{c}\text { Percentage of } \\
\text { respondents }(\%)\end{array}$} \\
\cline { 3 - 4 } & $\mathbf{n}$ & $\begin{array}{c}\text { Primary } \\
\text { role }\end{array}$ & $\begin{array}{c}\text { Important } \\
\text { role }\end{array}$ \\
\hline Provide training & 107 & 25.6 & 89.9 \\
Promotion & 103 & 24.6 & 86.6 \\
Provide infrastructure & 101 & 24.2 & 84.9 \\
Provide regulation & 107 & 25.6 & 89.9 \\
Total & $\mathrm{N}=119$ & 100 & \\
\hline
\end{tabular}

In many developing countries such as Indonesia, the government has played a major role in the evolution and development of the tourism industry. In this regard, in addition to the formulation of tourism policy frameworks and the development and initiation of the tourism development plans, governments in many developing countries have been actively engaged in tourism entrepreneurial activities, for example with regards to the operation and provision of hospitality and other tourism facilities and services (Armstrong 2012). There has been research explaining and justifying government involvement in tourism development and evolution not only in developing countries but also in other countries more generally (Hall 2011). The degree of active involvement in tourism development by government tends to reflect the importance of the tourism sector to the national or regional economy (Hall 2011). In community-based ecotourism, people-centric methods are a functional tool for moving towards rational benefits and elevating poverty, thereby inspiring the government and the community to preserve their natural and cultural resources (Armstrong 2012).

Governance involves the co-ordination of government, business, and civil society actors in a process whereby knowledge is shared and actions are identified and implemented to achieve mutually beneficial goals that 'steer' society in a certain direction (Beaumont and Dredge
2010; Hall 2011). Given the number of actors involved, effective governance systems require both the creation and maintenance of effective spaces of dialogue, communication, and knowledge interchange (i.e. governance processes) and formal administrative bodies that can develop and implement policies and regulatory frameworks (i.e. governance structures). These governance arrangements (both processes and structures) do not just exist but are dynamically created and modified over time by a range of actors involved in and affected by the problem. Issues change, actors move in and out of focus, knowledge flows, and actors act based on their interpretation of this information. In this way, effective governance is like a moving target. Governance structures and processes must be both locally appropriate and yet globally engaged (Beaumont and Dredge 2010).

Meanwhile, the findings of our research on community perception showed that government was considered equally responsible for providing training, promotion, infrastructure, and regulation. Looking at the situation in Indonesia, the government does tend to provide some of the infrastructure, promotion, and regulation, and these items are normally included in their annual budget allocations. However, some local governments in Indonesia do not provide infrastructure although they do provide promotion and regulation. Nevertheless, at both sites communities and governments have contributed to tourism development in their respective areas. For instance, the governments provided infrastructure such as signboards advertising whale shark tourism, and the communities provided facilities such as a video of the whale sharks for visitors to watch before going to see the whale sharks.

\section{Accessibility and supporting facilities}

Tourism relies heavily on four component elements: attraction, accessibility, accommodation and amenities (Armstrong 2012). These components played significant roles in the development of whale shark tourism watching development in the study area. In Botubarani, access from Gorontalo is relatively easy, with several options; the study revealed that most visitors used land transportation such as 
cars, motorbikes and bentor (kind of motorized tricycle taxi) to reach Botubarani, with the overland travel generally taking approximately 45 minutes to one hour. Visitors come to the visitor center and wait for their turn to see the whale sharks. During the waiting period, visitors watch a video on whale sharks and the code of conduct in order to help them better understand the trip. In Teluk Saleh, visitors generally used cars or buses to reach Labuhan Jambu village, where they would be accommodated in a homestay. They would then get up to take bego boat at 03.00 am to go to the bagan lift net. During their stay, visitors normally look around the village, visiting the harbor, fish market, etc.

In terms of accommodation, in Botubarani visitors could only stay in Gorontalo, where hotels and simple accommodation are available. In Labuan Jambu, the community provides simple accommodations such as homestays where visitors can stay with a host family and share experiences with them such as the local culture. At the time of the survey, there were seven homestays available in Labuhan Jambu which were ready to receive whale shark watching visitors. One important element at each site is that the actual whale shark watching experience required dedicated transportation by sea. The price for these boat trips was greatly influenced by the distance and varied between the locations. Table 5 shows a summary of transportation used by visitors to reach the two sites.

\section{Whale shark watching trips}

Visiting the whale shark watching spot can provide a range of different memorable experiences (Himawan et al. 2017). In Botubarani, the interaction area is only 50 meters from the beach. To see the whale sharks, people could snorkel or dive, while non-divers could watch from a small canoe. Divers or snorkellers generally arrive in a speed boat bringing them to the interaction area; these trips are operated by two local dive centers: Salvador Dive Centre and Miguel Dive Centre. Non-divers come first to the locket set up by the community and pay before getting into a canoe. Three people can fit into one canoe; although one person or two persons can use one canoe, they must pay for three persons.

In Labuhan Jambu, people have to book through an ecotourism operator to see the whale sharks. The ecotourism operator will then arrange the bego boat to take visitors to a bagan lift net. They will use the bagan as a platform for watching the whale sharks. Because of the long distance to reach the bagan lift nets, visitors normally leave Labuhan Jambu at 03.00 am and arrived at $05.30 \mathrm{am}$. Figure 9 shows the sea transport provided to see the whale sharks, including a bego boat in Labuhan Jambu (Figure 8.A) and small canoes in Botubarani (Figure 8.B).
Ecological knowledge to support conservation measures

Concerns have been raised over the ecological effects of tourism since 1960, when many scholars realized that the tourism industry had the capability to either moderately alter or completely transform destinations in adverse ways (Hall 2011). In the case of whale shark watching tourism, it is crucial to maintain the habitat and ecosystem used by whale sharks in order to ensure that this natural resource is available long term. Over the past decade, several whale sharks tagging studies have been initiated in various parts of the world (Haskell et at. 2015). In addition, Sequeira et al. 2012 conducted research in the western Indian Ocean and found a correlation between whale shark presence and sea surface temperature (SST) in the region.

Conservation International Indonesia has been conducting research to understand whale shark movements through a tagging program in Labuhan Jambu. Using "finmounted satellite tag" technology the program has placed tags in the dorsal fins of whale sharks that transmit whale shark position as well as depth and temperature data from their recent dives. Data provided by these tags will inform scientists to help design appropriate conservation measures (Conservation International Indonesia 2018). The BPSPL Makassar, a working unit from MMAF, has also conducted studies in Botubarani, Gorontalo. These studies are mainly aimed at understanding the behavior and movement patterns of this fish, and making information available to promote better management of whale shark tourism. In Labuhan Jambu, Conservation International has been collecting data such as photo-ID, seawater clarity, current velocity and conducting whale shark tagging. These data will be shared with the local government and used to inform the process of establishing an MPA or MPA network. Figure 10 shows the tracks of tagged whale sharks (A) and the tagging process in Teluk Saleh, Sumbawa (B).

Table 5. Transportation used by visitors to get to Botubarani and Labuhan Jambu $(\mathrm{n}=111)$

\begin{tabular}{lcccc}
\hline $\begin{array}{c}\text { Type of } \\
\text { transportation }\end{array}$ & Percentage & Freq. & $\begin{array}{c}\text { Number of means of } \\
\text { transportation used } \\
\text { by each visitor }\end{array}$ \\
\cline { 3 - 5 } & & & Mean & SD \\
\hline Car or buses & $55.0 \%$ & 61 & 1.98 & 1.191 \\
Boat & $5.4 \%$ & 6 & & \\
Plane and car & $28.8 \%$ & 32 & & \\
Plane and boat & $8.1 \%$ & 9 & & \\
Plane, car and & $2.7 \%$ & 3 & \\
boat & & & \\
Total & $100 \%$ & 111 & \\
\hline
\end{tabular}

Table 6. Doxey's irritation index related to tourism development in Botubarani Gorontalo and Labuhan Jambu Teluk Sale Sumbawa

\begin{tabular}{lll}
\hline Doxey's Irritation Index Stage & Botubarani Gorontalo & Labuhan Jambu Teluk Saleh Sumbawa \\
\hline Euphoria & Community support for whale shark tourism & Community support for whale shark tourism \\
Apathy & Community view tourism as a source of income & Community view tourism as a source of income \\
& generation in the village & generation in the village \\
Annoyance & Until now the community h this stage & Until now the community are not in this stage \\
Antagonism & Until now the community are not in this stage & Until now the community are not in this stage \\
\hline
\end{tabular}



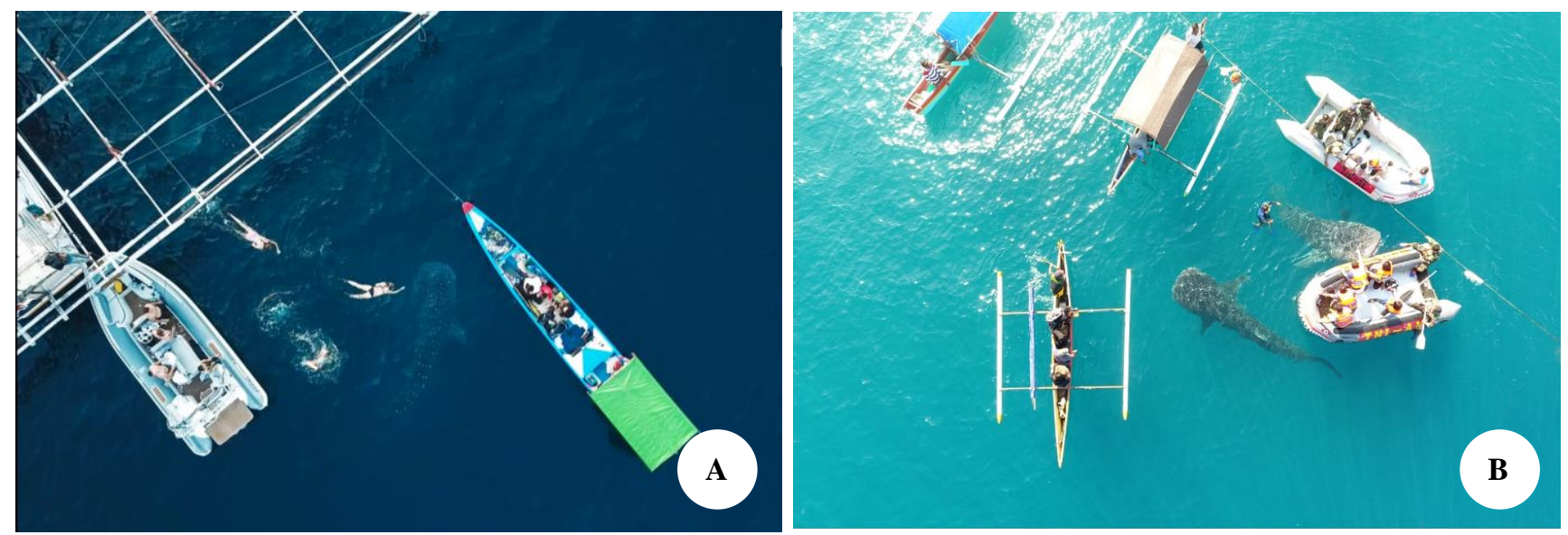

Figure 8. Types of sea transport: A. in Labuhan Jambu, Teluk Saleh, Sumbawa (Source: Sumbawa Amazing), B. in Botubarani, Gorontalo (Source: Oli Latif)
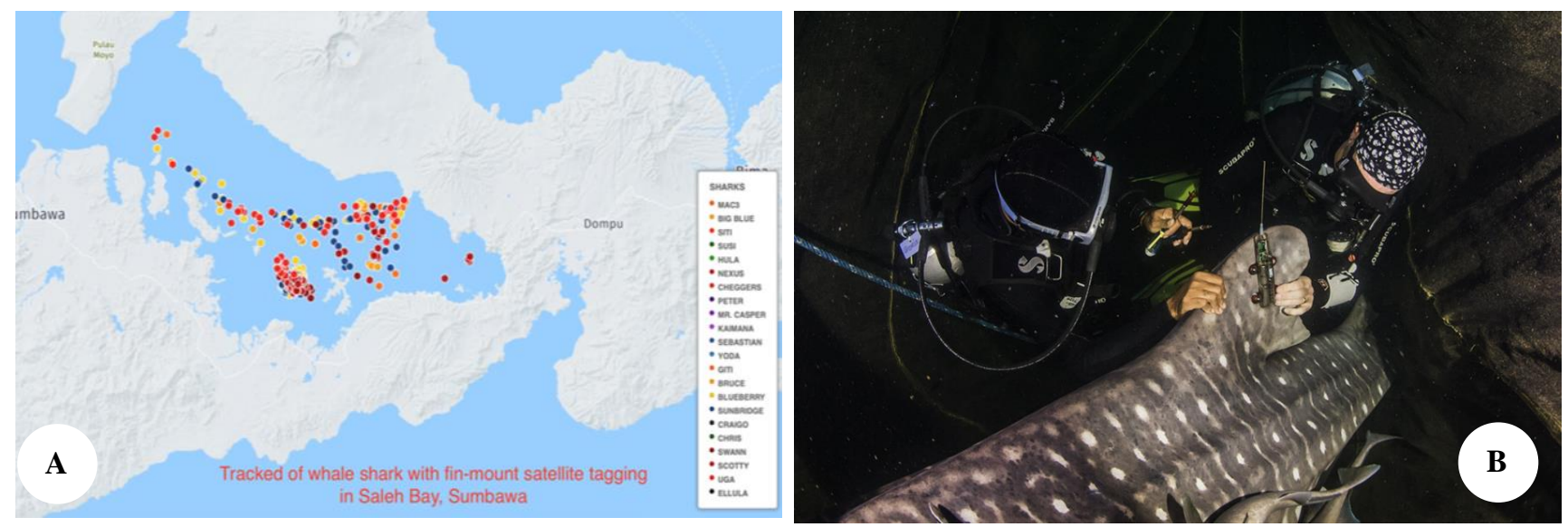

Figure 9. Whale shark tagging: A. Tracking data from tagged whale sharks; B. Tagging in Labuhan Jambu, Teluk Saleh, Sumbawa, Indonesia (Source: Conservation International Indonesia 2018)

\section{Socio-economic and cultural aspects of whale shark tourism}

Whale shark interactions are a key attraction for snorkel and divers; however, a lack of official management especially with respect to economic aspects, can affect the sustainability of the industry (Tibirica et al. 2011). Catlin et al. 2010 found that in Western Australia the whale shark tourism industry had developed at several locations (e.g. Coral Bay and Exmouth) and was valued at AUD 6 million annually.

Well maintained ecosystems and habitats will have a positive influence on the economic aspects of whale shark watching tourism in a positive way, through providing or maintaining income generation for locals and other relevant stakeholders. In Botubarani, a community tourism group (Pokdarwis) has been generating and managing income generated from whale shark watching tourism amounting to almost IDR 50 million per month. Meanwhile, in Labuhan Jambu the village enterprise agency (Bumdes) has been generating almost IDR 35 million per month. In addition, tourism can draw the attention of policymakers to the need to provide better infrastructure in destination areas (Haskell et al. 2015). However, lessons learned from other places such as Bali and Lombok indicate that, although communities in the destination areas have greater economic opportunities and tend to be able to achieve higher incomes than before, there are also many draw-backs (Beaumont and Dredge 2010). For example, in areas such as Bali, almost everything has become more expensive, including food and raw materials, and the price of land can also rise very rapidly once an area becomes a tourism destination.

Meanwhile, the socio-cultural aspect is extremely influential and needs to be considered carefully. Sociocultural is a hybrid term, widely used to refer to the traits, conditions, and changes in both social organization and the culture of a group of people (Hall 2011). Tourism can influence culture in a positive or negative way. For example, it might promote and help retain certain aspects of traditional culture or conversely accelerate their disappearance. It is not unusual for tourism to help nurture cultural activity in destination areas, including elements previously fading away. On the other hand, tourism can 
contribute to various social problems, for example through promoting the migration of people to destination areas looking for job opportunities, changes in lifestyle, etc.

It is interesting to look at Doxey's socio-cultural tourism development impact model (Hall 2011). This begins with a euphoria stage when residents begin to support tourism development and are ready to share their community with visitors. This stage is most likely to occur when local economies have been stagnant and tourism seems to offer new opportunities for growth. This support is based on economic projections that often tend to ignore or downplay social factors. The apathy stage may follow, in situations where tourism has become integrated and accepted as part of the community's economic base and is no longer a novelty. The social structure of the destination area may well have changed, e.g. with significant migrant influx, and local people may view tourism benefits as accruing to a limited number of residents (often migrants). Many no longer believe in the once hoped-for economic potential and job opportunities from tourism, and do not see tourism as an important factor in their lives and livelihoods. The irritation stage is likely to arise when tourism development has not been planned in sustainable way, for example in terms of zoning. Local residents must now share with outsiders' areas that used to be their own livelihood or recreational areas. If the environment or the attractiveness of the local area is drastically modified (reduced) through development, visitor numbers may decrease resulting in economic decline. At this time the poorly unplanned tourism development begins to receive attention and local residents perceive a loss of income or some other aspect of quality of life, and start to blame tourism for this loss. Finally, the situation may degrade to the stage of antagonism where the sense of lost income and place become more profound; residents start to blame tourists for the change rather than the unplanned and uncontrolled development processes which led to this situation. This situation may be further compromised as the type of tourist most likely to visit once the euphoria stage is over is likely to be an entirely new type of visitor, less interested in local customs and traditions and more drawn to specific physical attractions which may not be viewed as positive by local communities. Table 6 describes the tourism development process in Botubarani and Labuhan Jambu according to Doxey's irritation index.

As suggested in Table 6, the communities in the two study areas are still in the euphoria and (for some) possibly entering the apathy stage. Communities are supportive of whale shark tourism at both the sites and the income generated from this tourism is seen as important. In addition, whale shark tourism has started to become integrated with other programs that community has initiated. For instance, communities are providing souvenirs, tours around the village, and watching videos of whale sharks before visitors see this fish first hand.

\section{Governance factors affecting whale shark tourism}

Ecological, economic, social-culture and governance factors are crucial and need to be promoted in the day to day running of the business of tourism (Robinson et al.
2013). Linkages between these four factors are necessary and even inevitable in developing and implementing the increasingly popular paradigm of nature-based tourism centered on local communities. Ensuring the engagement and direct participation of local people in the initiation process will help further steps. In order to protect the object of interest, in this case, the whale shark population, it is vital to have a management plan to ensure the sustainable use of these animals for non-extractive tourism. Finally, comanagement or close cooperation among various stakeholders relevant is also important.

Managing stakeholder interests in the tourism sector needs integrated approaches. Factors involved in governance include controlling regulations, market regulations, contextual control, self-regulation, and cooperative management. Ideally, all these aspects should be taken into consideration when developing any naturebased tourism where communities are central to the development (Hall 2011). Good governance depends on the legitimacy of the political system and on the respect shown by the people for its institutions (Hall 2011). It also depends on the capacity of such institutions to respond to problems, and to achieve social consensus through agreements and compromise (Hall 2011). Governance is the complex of ways by which individuals and institutions, public and private, manage their common concerns (Hall 2011). In other words, governance is neither a system of rules nor an activity; it is a process; is not based on domination but on compromise; involves both private and public actors; is not necessarily formalized, and is generally based on an on-going interaction (Hall 2011).

With respect to the controlling regulations aspect, the government acts a regulator of social change and therefore establishes legally binding rules to control business activities, the utilization of natural resources, etc. (Hayombe et al. 2012). With respect to the market regulation aspect, the role of government is mainly as a facilitator of market processes, and in ensuring fairness in their implementation (Hayombe et al. 2012). In this context, the self-interest of government should be seen not as a problem but rather as a solution.

Our findings suggest that government has exercised, at least to some extent, its role and responsibility with respect to providing regulations. For example, the Minister of Marine Affairs and Fisheries issued Ministerial Decree No $18 /$ Kepmen-KP/2013 to fully protect the whale shark from exploitation, including capture as well as the trading of its meat, the whole body or any body parts.

Often the community is seen as social capital, in that they have shared norms and values and systems which can be activated by and for goals of mutual benefit (Hall 2011). The involvement of communities in tourism development should help to ensure good results during the processes involved, empowering civil society. Communities should be given an opportunity to play a key role and to create trust and co-management with other stakeholders.

In the aspect of contextual control and self-regulation, tourism operators, NGO, and community play a key role. We expect that these stakeholders should be able to voluntarily promote regulations and best practices during 
the implementation of whale shark watching tourism. There is a strong belief that if these social actors understand their working environment, then they know how to (i) manage their affairs without government help; (ii) solve their own problems; and (iii) take a lead in terms of planning and implementing an appropriate product.

Co-management is also important to promote collaboration during implementing of tourism development. At the local level, community development initiatives such as whale shark watching tourism have a better opportunity of being accepted by local people if developers acknowledge that different groups within a community want different things, including roles, functions and responsibilities. Establishing community cooperation to manage whale shark watching tourism activity at community level is good idea and might ensure better outcomes in many cases. One positive action at both sites is that every week the community set up a time to clean the beach in the whale shark tourism area.

In Botubarani, good governance is a key of success in developing whale shark tourism. With good governance, all stakeholders involved in this tourism may work together under its supervision. For example, the Department of Fisheries has worked with other government institutions such as the Department of Tourism and the community in establishing an information board on whale shark tourism in the area and in renovating the information centre in Botubarani. In contrast with Botubarani, in Labuhan Jambu good governance seems like something that still needs to be established. Working together among government institutions, private sector actors and other stakeholders needs to be initiated. Up until now, the community and Conservation International Indonesia have been working together, but not on the entire program, only in the photoID and tagging program (Conservation International Indonesia 2018). Hopefully in the next few months they will establish good governance during the implementation of the whale shark tourism program in this area.

In conclusion, when attempting to develop tourism in general, and wild-life tourism such as whale shark watching tourism in particular, there are many challenges and various factors that need to be considered and fully understood. This includes ecological, socio-cultural, economic and governance factors. The approach to establish a Marine Protected Areas including zoning system need to be considered. For example, the Marine Protected Area (MPA) in Botubarani has been reserved since 16 April 2019 with the decree of the Governor number 141/24/IV/2019. Meanwhile, in Labuhan Jambu Teluk Saleh an MPA is still under consideration by the local government of Sumbawa. Conservation International Indonesia has been collecting data such as photo-ID and tagging, current velocity and visibility to inform the local government in establishing the MPA around the area. In addition, factors such as environmental, social-cultural and economic have to be considered and included in tourism development. For instance, at both sites, environmental aspects such as plastic and marine debris have become a focus of attention for both the local government and community. Communities are central to development, as exemplified by the community meetings which became the basis for the development of whale shark tourism in Labuhan Jambu, Teluk Saleh. However, the economic aspect is a key factor driving communities to put effort into ensuring that whale shark tourism will be viable in the long-term in Botubarani and Labuhan Jambu.

\section{ACKNOWLEDGEMENTS}

We would like to express special thanks to the community of Botubarani, Gorontalo and Labuhan Jambu, Teluk Saleh, Sumbawa for participating in this research. We would also like to thank four enumerators: Sukirman Tilahunga and Oli Latif in Botubarani, and Ismail Marzuki and Muh. Ikbal Hidayat in Labuhan Jambu.

\section{REFERENCES}

Anna Z. 2017. Economic valuation of whale shark tourism in Cenderawasih Bay National Park, Papua, Indonesia. Biodiversitas J Biol Divers 18: 1026-1034.

Armstrong R. 2012. An analysis of the conditions for success of community-based tourism enterprises. ICRT Occas Pap 21: 1-52.

Arnstein SR. 1969. A ladder of citizen participation. J Am Plann Assoc 35 (4): 216-224.

Beaumont N, Dredge D. 2010. Local tourism governance: A comparison of three network approaches. J Sustain Tourism 18 (1): 7-28.

BPSPL. 2017. Hiu Paus di Pantai Botubarani, Gorontalo. [Indonesian]

Brooks K, Rowat D, Pierce SJSJ, Jouannet D, Vely M. 2011. Seeing spots: Photo-identification as a regional tool for whale shark identification. WIOMSA 9: 185-194.

Brunnschweiler JM. 2010. The Shark Reef Marine Reserve: a marine tourism project in Fiji involving local communities. J Sustain Tourism 18: 29-42.

Cárdenas-Palomo NJ, Herrera-Silveira I, Velázquez-Abunader O, Reyes, Ordoñez U. 2014. Distribution and feeding habitat characterization of whale sharks Rhincodon typus in a protected area in the north Caribbean Sea. J Fish Biol 86 (2): 668-66. DOI: 10.1111/jfb.12589

Catlin J, Jones T, Norman B, Wood D. 2010. Consolidation in a wildlife tourism industry: the changing impact of whale shark tourism expenditure in the Ningaloo coast region. Intl J Tourism Res 12: 134148.

Clua E, Buray N, Legendre P, Mourier J, Planes S. 2011. Business partner or simple catch? The economic value of the sicklefin lemon shark in French Polynesia. Mar Freshw Res 62: 764-770.

Compagno LJV. 2001. Sharks of the world. An annotated and illustrated catalogue of shark species known to date. Volume 2. Bullhead, mackerel and carpet sharks (Heterodontiformes, Lamniformes and Orectolobiformes). FAO Species Catalogue Fish Purposes 2 (1): 269. DOI: 10.1016/j.neuropharm.2006.07.020.

Conservation International Indonesia. 2018. Laporan Kegiatan Program Konservasi Hiu Paus (Rhincodon typus). Conservation International Indonesia, Jakarta. [Indonesian]

Daldeniz B, Hampton M. 2012. Dive tourism and local communities: Active participation or subject to impacts? Case studies from Malaysia Int J Tour Res 15 (5): 507-520.

De la Parra Venegas R, Hueter R, González Cano J, Tyminski J, Gregorio Remolina JJ. 2011. An unprecedented aggregation of whale sharks, Rhincodon typus, in Mexican coastal waters of the Caribbean Sea. PloS One 6: e18994. DOI: 10.1371/journal.pone.0018994.

Fitzpatrick R, Abrantes KG, Seymour J, Barnett A. 2011. Variation in depth of whitetip reef sharks: does provisioning ecotourism change their behaviour? Coral Reefs 30: 569-577.

Gallagher AJ, Hammerschlag N. 2011. Global shark currency: the distribution, frequency, and economic value of shark tourism. Curr Issues Tourism 14: 797-812.

Hall CM. 2011. A typology of governance and its implications for tourism policy analysis. J Sustain Tourism 19 (4\&5): 437-457. 
Haskell PJ, McGowan A, Westling A, Mendez-Jimenez A, Rohner CA Collins K, Rosero-Caicedo M, Salmond J, Monadjem A, Marshall $\mathrm{AD}$, Pierce SJ. 2015. Monitoring the effects of tourism on whale shark Rhincodon typus behaviour in Mozambique. Oryx 49 (3): 492 499.

Hayombe PO, Agong SG, Nystrom M, Mossberg L, Malbert B, Odede F. 2012. Upscaling ecotourism in Kisumu city and its environs: Local community perspective Author. Intl J Bus Soc Res 2 (7): 158-174.

Higginbottom K, Rann K, Moscardo G, David D, Muloin KS. 2001. Status Assessment of Wildlife Tourism in Australia: An overview. CRC for Sustainable Tourism, Gold Coast.

Himawan MR, Tania C, Noor BA, Wijonarno A, Subhan B, Madduppa H 2015. Sex and size range composition of whale shark (Rhincodon typus) and their sighting behaviour in relation with fishermen lift-net within Cenderawasih Bay National Park, Indonesia. AACL Bioflux 8 (2): 123-133

Himawan MZ, Tania C, Fadela SN, Bramandito A. 2017. Whale Shark Indonesia Project. [Final Report]. Bogor Agricultural University \& WWF-Indonesia, Jakarta.

Ihsan EN, Enita SY, Kunarso and Wirasatriya A. 2018. Oceanographic factors in fishing ground location of anchovy at Teluk Cenderawasih National Park, West Papua: Are these factors have an effect of whale sharks appearance frequencies? IOP Conf Ser Earth Environ Sci 116 012017. DOI: 10.1088/1755-1315/116/1/012017.

IUCN. 2011. IUCN Red List of Threatened Species. Version 2011.1. www.iucnredlist.org

Macena BCL, Hazin FHV. 2016. Whale shark (Rhincodon typus) seasonal occurrence, abundance and demographic structure in the midequatorial Atlantic Ocean. PLoS ONE 11 (10): 1-24. DOI 10.1371/journal.pone.0164440.

Motta PJ, Maslanka M, Hueter RE, Davis RL, De la Parra R, et al. 2010 Feeding anatomy, filter-feeding rate, and diet of whale sharks Rhincodon typus during surface ram filter feeding off the Yucatan Peninsula, Mexico. Zoology (Jena, Germany) 113: 199-212.

Nikkhah HA, Redzuan M. 2009. Participation as a medium of empowerment in community development. Eur J Soc Sci 11 (1): 170176.

Olii AH, Sahami FM, Hamzah SN, Pasisingi N. 2017. Preliminary findings on distribution pattern of larvae of nike fish (Awaous sp.) in the estuary of Bone River, Gorontalo Province, Indonesia. AACL Bioflux 10 (5): 1110-1118.

Pierce SJ, Mendez-Jimenez A, Collins K, Rosero-Caicedo M, Monadjem A. 2010. Developing a Code of Conduct for whale shark interactions in Mozambique. Aquat Conserv: Mar Freshw Ecosyst 20: 782-788.
Pierce SJ, Norman B. 2016. Rhincodon typus (The IUCN Red List of Threatened Species 2016) e.T19488A2365291

Ranintyari M, Sunarto, Syamsuddin ML, Astuty S. 2018. Effects of oceanographic factors on spatial distribution of whale shark in effects of oceanographic factors on spatial distribution of whale shark in Cendrawasih Bay National Park, West Papua. IOP Conf Ser: Earth Environ Sci 149: 012050. DOI: 10.1088/1755-1315/149/1/012050.

Riley MJ, Hale, MS, Harman A, Rees RG. 2009. Analysis of whale shark Rhincodon typus aggregations near South Ari Atoll, Maldives Archipelago. Aquat Bio 8 (2): 145-150. DOI: 10.3354/ab00215.

Robinson DP, Jaidah MY, Jabado RW, Lee-Brooks K, Nour El-Din NM. 2013. Whale sharks, Rhincodon typus, Aggregate around offshore platforms in Qatari Waters of the Arabian Gulf to Feed on Fish Spawn. PLoS ONE 8 (3): e58255. DOI: 10.1371/journal.pone.0058255

Rowat D, Brooks K, March A, McCarten C, Jouannet D. 2011. Longterm membership of whale sharks (Rhincodon typus) in coastal aggregations in Seychelles and Djibouti. Mar Freshw Res 62 (6): 621627.

Rowat D, Brooks KS. 2012. A review of the biology, fisheries and conservation of the whale shark Rhincodon typus. J Fish Biol 80 (5): 1019-1056. DOI: 10.1111/j.1095-8649.2012. 03252.xz

Sequeira A, Mellin C, Rowat D, Meekan MG, Bradshaw CJA. 2012. Ocean-scale prediction of whale shark distribution. Divers Distrib 18: 504-518.

Tania C. 2014. Pemantauan dan Studi Hiu Paus di Taman Nasional Teluk Cenderawasih. Laporan Pemantauan dan Studi Tahun 2011-2013, Wasior. [Indonesian]

Tibirica Y, Birtles A, Valentine P, Miller DK. 2011. Diving tourism in Mozambique: An opportunity at risk?. Tourism Mar Environ 7: 141151.

UNEP 2011. Towards a Green Economy: Pathways to Sustainable Development and Poverty Eradication. United Nations Environment Programme, Nairobi, Kenya

Vianna GMS, Meekan MG, Pannell DJ, Marsh SP, Meeuwig JJ. 2012. Socio-economic value and community benefits from shark-diving tourism in Palau: A sustainable use of reef shark populations. Biol Conserv 145: 267-277.

Yulianto I. 2016. Profil Perikanan Tangkap. [Report to the World Conservation Society]. WCS-Indonesia, Bogor. [Indonesian]

Zhang H, Lei SL. 2012. A structural model of residents' intention to participate in ecotourism: the case of a wetland community. Tourism Manag 33 (4): 916-925. 